\title{
Çocuk İstismarına İletişimsel Yaklaşım: Sınıf Öğretmenlerinin İletişimsel Deneyimleri ve Yeterlilikleri Üzerine Bir İnceleme*
}

\author{
Metin EKEN**
}

ÖZ

Türkiye Ulusal Ajansı tarafindan yürütülmekte olan Erasmus+ Programı Okul Eğitimi Stratejik Ortaklıklar eylemi kapsamında finanse edilen ProChild kısa adıyla "Çocuk İstismarını Tespit ve Önlemeye Yönelik Öğretmen Yeterliliklerinin Güçlendirilmesi”" Projesi kapsamında hazırlanan bu çalışma, çocuk istismarına iletişimsel yaklaşım aşamaları çerçevesinde sınıf öğretmenlerinin iletişimsel deneyim ve yeterliliklerini konu edinmektedir. Araştırmada nitel araştırma yaklaşımlarından fenomenoloji deseni kullanılmışıtı. Çalışma grubu Kayseri'de kamu okullarında görev yapan 8 sınıf öğretmeni ve çocuk istismarına ilişkin olarak sınıf öğretmenlerinin öğrencilerle kurdukları iletişimin şekillenmesindeki etki ve yönlendirmeleri sebebiyle 3 rehber öğretmenden oluşturulmuştur. Odak grup görüşmesi ve yarı yapılandırılmış derinlemesine mülakat teknikleriyle toplanan veriler, çalışma kapsamında kurgulanan tematik çerçevede analiz edilmiştir. Araştırma bulgularına göre katılımcıların, cinsel ve fiziksel istismar türlerine duygusal istismar ve ihmale oranla daha yüksek bir duyarllık ve ilgiyle yaklaştıkları görülmüştür. Bunun en temel sebebi ise istismar türlerine ilișkin bilgi ve farkındalık eksikliği olarak somutlaşmaktadır. Söz konusu eksiklik; istismarın tespiti, raporlanması ve adli bildirim, destek ve izleme süreçleri ile önleyici iletişim yaklaşımlarının geliştirilmesinin önündeki en önemli engellerden birini teşkil etmektedir. Bunun dışında, bahsi geçen her bir aşamada öğretmen, veli, eğitim süreçleri ve okul yönetimi kaynaklı önemli iletişim engellerinin ortaya çıktığı görülmektedir. Söz konusu bilgi eksikliği ve iletişim engellerine yönelik çözüm önerilerinin geliştirilmesi, istismara ilişkin okul toplumu üyelerinin tamamını ilgilendiren karmaşık sorunlara yanıtlar üretilebilmesi için önemli bir gereklilik arz etmektedir.

Anahtar Kelimeler: İletişim, Çocuk İstismarı, Sınıf Öğretmenleri.

\section{The Communicative Approach to Child Abuse: A Study on the Communicative Experiences and Competencies of Primary School Teachers}

\begin{abstract}
This study, which was prepared within the scope of the "Strengthening Teacher Competencies for the Detection and Prevention of Child Abuse" Project by the short name ProChild funded under the Erasmus+ Program Strategic Partnership for School Education actions carried out by the Turkish National Agency, addresses communicative experiences and competencies of primary school teachers within the framework of the stages of the communicative approach to child abuse. The study was conducted with the phenomenologic design among the qualitative study approaches. The study group included eight primary school teachers who worked in public schools in Kayseri, Turkey, and three counselor teachers due to their influence and guidance on shaping primary school teachers' communication with students regarding child abuse. Data were collected through focus group interviews and semi-structured in-depth interview techniques and were analyzed within the thematic framework set up in this study. According to the results of the study, the participants approached sexual and physical abuse types with more sensitivity and concern compared to emotional abuse and neglect. The main reason for this is the lack of knowledge and awareness regarding the types of abuse. This deficiency is one of the most important obstacles to the development of preventive communication approaches with the detection, reporting, and legal notice, support, and monitoring processes. Additionally, it is observed important communication barriers due to teachers, parents, educational processes and school administration arise at each aforementioned stage. It is highly necessary to develop solution proposals for the abovementioned lack of knowledge and communication barriers to provide answers to complex problems that concern all members of the school community regarding abuse.
\end{abstract}

Keywords: Communication, Child Abuse, Primary School Teachers.

\section{Giriş}

Çocuk istismarı; "18 yaş altındaki çocukların sorumluluk, güven ya da güç ilişkisi bağlamında karşı karşıya kaldıkları; sağlık, gelişim, haysiyet gibi yaşamsal değerlere fiili ya da potansiyel zarar verebilecek her

\footnotetext{
* Bu çalışma, ProChild kısa adıyla "Çocuk İstismarını Tespit ve Önlemeye Yönelik Öğretmen Yeterliliklerinin Güçlendirilmesi” başlı̆̆ıyla Türkiye Ulusal Ajansı tarafindan yürütülmekte olan Erasmus+ Programı Okul Eğitimi Stratejik Ortaklıklar eylemi kapsaminda desteklenmektedir.

** Dr. Öğr. Üyesi., Erciyes Üniversitesi, metineken@erciyes.edu.tr

Makalenin Gönderim Tarihi: 06.11.2020; Makalenin Kabul Tarihi: 03.12.2020
} 
türden fiziksel ve duygusal kötü muamele, cinsel istismar, ihmal ve kayıtsızlık ile diğer istismar biçimlerini içerir" (WHO, 2016).

Bir çocuğun fiziksel istisman; çocuğa karşı kasıtlı olarak kullanılan fiziksel güç sonucunda, çocuğun sağlı̆̆1, yaşamı, gelişmesi veya onuru açısından zararlı durumların ortaya çıkması -veya çıabilecek olmasışeklinde tanımlanır. Bu tanım çerçevesinde değerlendirilebilecek hareketler; vurma, tekmeleme, sarsma, ısırma, boğazını sıkma, yaralama, yakma, zehirleme, boğma vb. olabilir. Evlerde ise, çocuklara karşı fiziksel şiddete çoğu kez cezalandırma amacıyla başvurulur (Butchart vd., 2016, s. 10). Aile bireyleri, akrabalar, bakıcı ve öğretmen gibi sorumlu yetişkinler fiziksel istismar kaynaklanı arasında yer alabilir. Deri yaralanmaları (ekimoz/morarma/deri içi kanama, sıyrık, ssırlk yanık), iskelet sistemi lezyonları (kırk, çıkık), iç organ yaralanmaları ve daha çok hekim tetkikleri sonrasında anlaşlabilecek diğer göstergeler fiziksel istismarın teşhis edilmesini sağlayan temel bulgular arasındadır (Koç vd., 2014). Ancak tek bir yara veya belirtinin istismarnn teşhisi için yeterli olmadığı literatürde sıklıkla vurgulanmakta, suiistimali makul bir güvenle tanımlamak için yaralanma ile birlikte nesnel, kapsamlı bir tıbbi ve psikolojik değerlendirmenin gerekliliğine dikkat çekilmektedir (Christian \& States, 2017). Ayrıca çocuklarda kazalara bağlı yaralanmaların sık görülmesi sebebiyle yaşa uygun olmayan, kendi kendine olma olasillğı düşük olan hasarların makul şüpheyi arttıran unsurlar olduğu ifade edilmektedir (Kara vd., 2004, s. 142).

Duygusal istismarda temelde bir ebeveynin veya bakıcının, bir süreç içinde, çocuğa gelişimi açısından uygun ve destekleyici bir ortam sağlamadaki başarısızlığı söz konusudur (Butchart vd., 2016, s. 10). Her ne kadar daha pasif bir görünüm arz etse de ihmal davranışlarılyla birlikte aktif niteliğe sahip istismar biçimlerini de içerebilmektedir. Küçümseme/aşağılama (sözlü ve sözsüz reddetme/aşağılama); terörize etme (çocuğu tehdit eden davranışlar ya da çocuğa fiziksel olarak zarar verme, çocuğu veya çocuğun sevdiği nesneleri tehlikeye atma olasllığ); sömürme/bozma (çocuğu uygunsuz davranışlar geliştirmeye teşvik etmek); duygusal duyarlllığın inkâr edilmesi (çocuğun etkileşim gereksinimlerini göz ardı etmek, çocuğa olumlu etki göstermemek, çocukla etkileşimlerde duygusuzluk); izole etme (çocuğun yaşıtlarıyla veya yetişkinlerle etkileşim ve iletişim kurma imkânlarını kısıtlama); zihinsel, sağlıkla ilgili, tıbbi ve eğitimsel ihmal (çocuğun ihtiyaçlarını karşılamamak veya görmezden gelmek) biçimlerinde ortaya çıkabilir (APSAC, 1995). Soyutlanma, aşırı benimseyici davranış, intihar girişimi, alışkanlık haline gelmiş bozukluklar (tırnak yeme, saç çekme vb.), davranış bozuklukları, engellenmişlik (kendini ifade edememe vb.), saplantılar, amaç ya da yönelme eksikliği, depresyon, panik, korku, iticilik, zayıf davranış kontrolü, kendine zarar verme, hiperaktivite gibi davranışlar ise duygusal istismarın temel göstergeleri arasındadır (Veltkamp \& Miller, 1994)". "Duygusal istismar ve ihmal oldukça sık olmakla birlikte, fark edilmesinde, tanımlanmasında ve yasal olarak kanıtlanmasında diğer istismar türlerine göre daha fazla güçlük yaşanmaktadır. Ayrıca fiziksel ve cinsel istismar türlerinin çoğunda duygusal istismar ve ihmal de yer almaktadır" (Öztürk, 2007, s. 28).

Cinsel istismar ise çocuğun, kendisinin tam olarak kavrayamadığı, tam onay vermesi mümkün olamayacak veya gelişme düzeyi açısından hazır olmadığı ya da toplumun verili yasalarını veya toplumsal tabularını ihlal eden bir cinsel etkinliğe dâhil edilmesi olarak tanımlanır. Çocukların cinsel istismarında failler; yaşları gereği, mağdur üzerinde belirli bir yetki, otorite veya sorumluluk taşıyan yetişkinler olabileceği gibi, başka çocuklar da olabilir (Butchart vd., 2016, s. 10). Temas içermeyen türler (seksi konuşma, teşhir, röntgencilik), cinsel dokunma, oral-genital ilişki, interfemoral (genital sürtünme) ilişki, cinsel penetrasyon, cinsel sömürü (çocuk pornografisi, çocuk fuhuşu) gibi biçimlerde ortaya çıkabilir (Polat, 2019, ss. 101-105). Cinsel istismarın fiziksel göstergeleri temelde hekim muayenesiyle teşhis edilebilen bulgulardır. Psikolojik ve davranışsal düzeyde; yaş ve gelişim özelliklerine ve farklı koşullara göre değişebilen suçluluk, utanç, üzüntü, öfke, kayg1, çaresizlik, depresyon vb. gibi durumlar; bilişsel/gelişimsel/akademik düzeyde ise öğrenme güçlüğü, dağılmış ilgi-dikkat eksikliği, akademik başarısızlık gibi temel göstergeler cinsel istismara yönelik belirtiler olabilir (Şahin vd., 2008, s. 10). İstismarın fark edilmesi çoğu zaman tesadüfi olabilmektedir. Birinin anormal davranışı fark etmesi, herhangi bir fiziksel yaralanma sonucu doktora başvurma ya da daha nadir görülse de istismar edilen kişinin üçüncü bir şahsa durumu anlatması gibi şekillerde fark edilebilmektedir. (Polat, 2019, s. 107). Bu nedenle özellikle psikolojik ve davranışsal olarak gözlemlenebilen bazı belirtiler her zaman istismar için yeterli kanıtı oluşturmayabilir. 
İhmal'e gelindiğinde bir ebeveynin veya başka bir aile üyesinin, aslında mümkünken, çocuğun gelişimi ve esenliği için yapılması gerekenleri yapmaması durumuyla karşı karşıya kalınmaktadır. Bu tanımıyla ihmal; sağlık, eğitim, duygusal gelişim, beslenme, barınma ve güvenli yaşam koşulları gibi unsurlar çerçevesinde gelişebilir (Butchart vd., 2016, s. 10). Kötü beslenme işaretleri gösteren sürekli açlık belirtileri, hijyensiz vücut ve giyim belirtileri, uygun olmayan k1yafetler, denetimsizliğin sürekliliği, ihmal edilmiş fiziksel sorunlar ve tıbbi bakım, normal kilonun altında olma, kötü gelişim şekilleri, büyüyememe, sürekli uykusuz görünme gibi fiziksel göstergeleri olabilir. Yine kendine zarar verme, yorgunluk, halsizlik, düşük benlik algisı, sosyal sorunlar, yakınlı kuramama, ilgi ihtiyacı gibi davranışsal ve duygusal göstergelerle birlikte devamsızlık sorunu, öz disiplinsizlik, öğrenme zorluğu gibi gelişimsel ve akademik göstergeleri olabilir (Şahin vd., 2008, s. 15).

Son yıllarda Türkiye özelinde bu konuda yayımlanan istatistiki veriler, yukarıda temel türleri ifade edilen sorunun yaygın şekilde görülmesinin yanı sıra çocukların yüksek yararının gözetilmesi için titizlikle çalsssllması gereken bir mesele olduğunu göstermektedir. Ayrıca veriler bilimsel bilginin ve bu bilginin politikalara ve eğitimlere yansıtılmasının önemini artırmakta, bu konudaki işbirliklerini önemli kılmaktadır. Bu çerçevede Türkiye Ulusal Ajansı tarafından yürütülmekte olan Erasmus+ Programı Okul Eğitimi Stratejik Ortaklıklar eylemi kapsamında finanse edilen ProChild kısa adıyla "Çocuk İstismarını Tespit ve Önlemeye Yönelik Öğretmen Yeterliliklerinin Güçlendirilmesi” Projesi kapsamında hazırlanan bu çalısma, çocuk istismarına iletişimsel yaklaşım aşamaları çerçevesinde sınıf öğretmenlerinin iletişimsel deneyim ve yeterliliklerini konu edinmektedir.

İlgili politika ve eğitimlere yansittlabilecek nitelikteki bilimsel bilgi, istismarla mücadele meslek gruplarının mesleki formasyonlarının güçlendirilmesi açısından son derece önemlidir. Bu süreçte bilgi, beceri ve farkındalıkları arttırılması gereken grupların başında ise öğretmenler gelmektedir. Farklı düzeylerdeki öğretmenlerin istismar süreçlerindeki rolü, önemi, bilgi ve farkındalıkları pek çok araştırmaya konu edilmiştir. Bunların bir kısmı genel bir nitelik arz ederken (Erol, 2007; Scholes vd., 2012) önemli bir diğer kısmı ise sınıf öğretmenlerinin (Bülbül vd., 2019; Vitalaki, 2013) ve özelde rehber öğretmenlerin rolüne (Cowan vd., 2019; Kemp, 1981; Yolcu, 2009) ilişkindir.

Bu çalışma, çocuk istismanna iletişimsel yaklaşımda, öğretmenlerin neyi nasıl deneyimlediklerine ilişkin dört aşamalı bir yaklaşım çerçevesinde öğretmenlerin iletişimsel deneyim ve yeterliliklerine odaklanmayı amaçlaması bakımından yenilikçi bir görünüm arz etmektedir. Bu çerçevede nitel bir karakterde, fenomenolojik araştırma deseni ile tasarımlanmış çalışmada 8 sınıf öğretmeni ve 3 rehberlik servisi öğretmeni ile bir odak grup görüşmesi ve derinlemesine mülakatlar gerçekleştirilmiştir. Bu genel amaç ve tasarım çerçevesinde aşağıdaki sorulara yanıtlar aranmışır:

1. Sınıf öğretmenleri çocuk istismarını nasıl algılamaktadır ve istismara ilişkin ne gibi tecrübeler yaşamışlardır?

2. Sınıf öğretmenlerinin istismarı tespit etmelerini kolaylaştıran iletişimsel yaklaşıma ilişkin algı ve deneyimleri nelerdir?

3. Sınıf öğretmenlerinin istismarın raporlanması ve adli bildirim sürecindeki iletişimsel yeterliliklere ilişkin alg1 ve deneyimleri nelerdir?

4. Sınıf öğretmenlerinin istismar vakaları sonrasındaki destek ve izleme süreçlerine yönelik iletişimsel yaklaşıma ilişkin algı ve deneyimleri nelerdir?

5. Sınıf öğretmenlerinin istismara ilişkin önleyici iletişim ve eğitim yaklaşımlarına yönelik alg1 ve deneyimleri nelerdir?

\section{Araştırma Metodolojisi}

Öğrencilerle yoğun bir etkileşim kuran sınıf öğretmelerinin iletişimsel deneyimlerine ve bu deneyimler çerçevesinde çocuk istismarına yönelik geliştirdikleri alg1 ve yaklaşımlara odaklanan bu araştırmada, insanların deneyimlerini nasıl yorumladıklarına ve onlara nasıl bir anlam yüklediklerine odaklanan nitel araşırma metodolojisinden yararlanılmışur (Merriam, 2015, s. 5). Nitel araştırma yaklaşımlarından ise bireylerin yaşanmış deneyimlerini ve ele alınan fenomene ilişkin hem öznel hem de diğer insanlarla ortak nesnel deneyimlere nasıl sahip olduklarını açılamaya olanak sağlaması bakımından fenomenolojik yaklaşım benimsenmiştir (Creswell, 2018, s. 79). 


\subsection{Araştırma Grubu}

Nitel araştırmalarda araştırma sonuçlarının evrene genellenmesinden ziyade ele alınan konunun derinlemesine incelenmesi amaçlandığından, araştırmacının bireyleri ve mekânları çalışmanın amaçlanı çerçevesinde seçmesi anlamına gelen amaçlı örneklem tercih edilmektedir (Creswell, 2018). Bu bağlamda çalışmada amaçlı örnekleme türlerinden ölçüt örnekleme tekniği kullanılmıştr. Ölçüt örneklemede katılımcılar, araştırmacının kurguladığı ölçütler çerçevesinde belirlenir. Bu araştırmada kullanılan temel ölçüt katılımcıların sınıf öğretmeni olmasıdır. Sınıf öğretmenleri, öğrencilerle çokça vakit geçirmeleri ve onları yakından tanıma imkânına sahip olmaları bakımından çocuk istismarının tespiti ve önlenmesine ilişkin anahtar bir rol üstlenmeleri bakımından ölçüt olarak alınmıştır. Bu çerçevede Kayseri ilinde görev yapan 8 sınıf öğretmeni ile görüşmeler gerçekleştirilmiştir. Çalışma kapsamında ayrıca okullarda çocuk istismarı süreçlerine yönelik aktif bir rol üstlenmeleri, sınıf öğretmenlerinin söz konusu süreçlerde en yakın irtibat noktaları olmaları, özellikle çocuk istismarına ilişkin olarak sınıf öğretmenlerinin öğrencilerle kurdukları iletişimin şekillenmesindeki etki ve yönlendirmeleri sebebiyle 3 rehberlik servisi öğretmeni ile de yan görüşmeler gerçekleştirilmiştir.

Tablo 1. Katıllımcıların Kod İsimler, Yaş, Cinsiyet, Mesleki Kıdem ve Branşa Göre Dağı̆lımı

\begin{tabular}{|c|c|c|c|c|c|}
\hline & İsim(Kod) & Yaş & Cinsiyet & Mesleki Kıdem Y1l & Branş \\
\hline $\mathbf{1 .}$ & Ayşe & 45 & Kadın & 23 Yıl & Sınıf Öğretmeni \\
\hline $\mathbf{2 .}$ & Şahin & 41 & Erkek & 16 Yıl & Sınıf Öğretmeni \\
\hline $\mathbf{3 .}$ & Ali & 41 & Erkek & 17 Yıl & Sınıf Öğretmeni \\
\hline $\mathbf{4 .}$ & Şebnem & 43 & Kadın & 21 Yıl & Sınıf Öğretmeni \\
\hline $\mathbf{5 .}$ & Rumeysa & 33 & Kadın & 9 Yıl & Sınıf Öğretmeni \\
\hline $\mathbf{6 .}$ & Gülşah & 43 & Kadın & 20 Yıl & Sınıf Öğretmeni \\
\hline $\mathbf{7 .}$ & Ayşenur & 24 & Kadın & 2 Yıl & Sınıf Öğretmeni \\
\hline $\mathbf{8 .}$ & Nergis & 26 & Kadın & 3 Yıl & Sınıf Öğretmeni \\
\hline $\mathbf{9}$ & Fatma & 39 & Kadın & 15 Yıl & Rehber Öğretmen \\
\hline $\mathbf{1 0 .}$ & Selahattin & 35 & Erkek & 12 Yıl & Rehber Öğretmen \\
\hline $\mathbf{1 1 .}$ & Tülay & 34 & Kadın & 11 Yıl & Rehber Öğretmen \\
\hline
\end{tabular}

\subsection{Veri Toplama Süreci}

Veri toplama sürecinde ilkin, tüm katıllmcılarla genel çerçevenin çizilmesini amaçlayan yüz yüze bir odak grup görüşmesi gerçekleştirilmiş ve sonrasında her bir katılımcıdan gerekli verilerin alınması amacıyla yarı yapılandırılmış görüşme formu kullanılmıştur. Derinlemesine görüşmeler online video görüşme platformlanı aracilğ̆yla gerçekleştirilmiştir. Odak grup görüşmesi, öğretmenlerin etkileşiminde ortaya çıkabilecek genel anlamların yakalanabilmesi amacıyla; yarı yapılandırılmış görüşme sorularını içeren mülakat tekniği ise açıklığa kavuşturulması istenen soru ve sorunların, katılımcıların kendi algılama ve anlama düzeyleriyle anlaşılmasına imkân vermesi sebebiyle çalışmanın amaçlarıyla uyumlu görülmüştür (Merriam, 2015, s. 87-88). Odak grup görüşmesinde kullanılan soru formu ve yarı yapılandırılmış görüşme formu, araştırmacı tarafindan gerçekleştirilen detaylı literatür taraması çerçevesinde oluşturulmuş ve iç geçerliliğinin sağlanması amacıyla da iki uzmanın görüşleri çerçevesinde yapılandırılmıştır. Ayrıca yapılandırılmış formun test edilmesi amacıyla bir pilot görüşme yapılmıs, geri bildirimler çerçevesinde sorularda kısmi revizyonlar gerçekleştirilmiştir.

Araştırma sorularının belirlenmesinde çalışmanın temel amaçları çerçevesinde ve ele alınan fenomene ilişkin olarak katlımcıların neyi nasıl deneyim ettiklerinin sistematik olarak somutlaştırılması amacıyla 4 aşamalı bir yaklaşım benimsenmiştir. Bunlar aşağıdaki şekilde ifade edilebilir:

\section{Aşama: Çocuk İstismarı; Türleri ve Kategorik Kavrayı̧̧ Kriterlerinin Belirlenmesi}

Çalışmanın giriş kısmında da sunulduğu üzere çocuk istismarı çalışmada; fiziksel istismar, duygusal (psikolojik) istismar, cinsel istismar ve ihmal olmak üzere 4 temel biçimde ele alınmıştır. Ayrıca öğretmenlerin söz konusu istismar türlerine ilişkin iletişimsel yeterliliklerinin kategorik bir biçimde ele alınması amacıyla bu türler; kaynak/lanı (istismarın potansiyel sorumluları), temel biçimleri (görünümler, alt türler) ve temel göstergeleri (fiziksel, davranışsal, duygusal, bilişsel göstergeler) çerçevesinde somutlaştırilmıştır. 
Tablo 2. İstismar Türleri ve Kategorik Kavrayış Kriterleri

\begin{tabular}{c|c|c|c}
\hline Fiziksel İstismar & Duygusal İstismar & Cinsel İstismar & İhmal \\
\hline İstismar Kaynağı, Temel Biçimler, Temel Göstergeler (Fiziksel, Psikolojik, Bilişsel/Gelişimsel/Akademik)
\end{tabular}

\section{Aşama: Çocuk İstismarına İletişimsel Yaklaşım Aşamalarının Belirlenmesi}

İstismar türlerinin somutlaştırlması; her bir istismar türüne dair olası kaynakların, temel biçimlerin ve göstergelerin ifade edilmesi, iletişimsel yeterlilik çerçevesinin belirlenmesi için önemli bir basamak olmakla birlikte bu çerçevenin somutlaştırılması yeni sınırlayıcı yaklaşımları gerekli kılmaktadır. Bu bağlamda çalışmada istismar vakalarına yönelik öğretmen ve aile merkezli rehberlerden hareketle (Şahin vd., 2008; Tower, 1992) iletişimsel yaklaşımı somutlaştracak dört aşama belirlenmiştir.

Tablo 3. Çocuk İstismarına İletişimsel Yaklaşımda Dört Aşama

\begin{tabular}{|c|c|c|c|}
\hline 1. Tespit ve Yaklaşım İletişimi & $\begin{array}{l}\text { 2. Raporlama, Bildirim } \\
\text { Iletişimi }\end{array}$ & 3. Destek ve İzleme İletişimi & 4. Önleyici İletişim \\
\hline $\begin{array}{l}\text { İstismar vakasının tespiti, okul } \\
\text { rehberlik sevisi ve okul yönetimi } \\
\text { ile uygun yaklaşımı sergileme }\end{array}$ & $\begin{array}{l}\text { Sürecin raporlanması ve } \\
\text { ilgili yasalar çerçevesinde } \\
\text { adli bildirimin yapilması }\end{array}$ & $\begin{array}{l}\text { Vaka tespiti ve raporlama } \\
\text { süreci sonrasında iletişimsel } \\
\text { destek ve izleme süreçleri }\end{array}$ & $\begin{array}{c}\text { Önleyici iletişimsel } \\
\text { yaklaşımla vaka } \\
\text { olasılıklarını azaltma }\end{array}$ \\
\hline
\end{tabular}

\section{Aşama: Etkili İletişimin Temel İlkelerinin Belirlenmesi}

İstismar vakalarına yaklaşımın iletişimsel perspektiften ele alınması ayrıca iletişimin etkililiğini de göz önünde bulundurmayı gerekli kılmaktadır. Elbette etkili iletişimin temel doğruları olmakla birlikte özel iletişim durumları, farklı ve ayrıntılı kurallar gerektirmektedir (Sezer, 2017, s. 36). Bu çerçevede genelde etkili iletişimin özelde ise çocuk istismarına yönelik etkili iletişimin temel ilkeleri Yüksel-Şahin'in (2016, ss. 53-55) kapsamlı yaklaşımından hareketle aşağıdaki şekilde kurgulanmıştır:

Tablo 4. Etkili İletişimsel Yaklaşımın Temel İlkeleri

\begin{tabular}{|l|l|}
\hline 1. Saygı & 6. Ben Dili Kullanma \\
\hline 2. Empatik Yaklaşım & 7. Tam ve Tek Mesaj Yollama \\
\hline 3. Etkin Dinleme & 8. Güvengen Davranma \\
\hline 4. Somut Konuşma & 9. Saygı Temelli Saydamlık \\
\hline 5. Uygun Bir Biçimde Kendini Açma & 10. Sözel-Sözel Olmayan Davranış Uyumu \\
\hline
\end{tabular}

\section{Aşama: İletişimsel İlkelerin Somut Davranışsal Karşılıklarının Belirlenmesi}

$\mathrm{Bu}$ noktada iletişimsel yeterlilik çerçevesinin somutlaştırılması için bir diğer gereklilik de söz konusu ilkelerin, çocuk istismarına iletişimsel yaklaşımın her bir aşamasındaki davranışal karşılıklarının neler olabileceğini ortaya koymaktır. Böylelikle hem öğretmenlerle yapılan görüşmelerde kullanılacak soru formunun zemini oluşturulmuş hem de elde edilen görüşme verilerinin değerlendirilmesi sürecinde işlevsel bir rehbere erişilmiştir. Dört aşamada iletişimsel yaklaşımın davranışsal karşılıklarını belirlemek amacıyla, genel iletişim becerilerine ve öğretmen iletişim becerilerine yönelik ölçeklerden (Buluş vd., 2017; Korkut Owen \& Bugay, 2014; Yildiz vd., 2018) ve öğretmen, aile ve diğer ilgililerin çocuk istismarılyla mücadele süreçlerinde yararlanabilecekleri rehberlerden (Şahin vd., 2008; Tower, 1992; Unicef, 2015) faydalanılmıştır.

Tablo 5. Tespit ve Yaklaşım İletişimine Yönelik Davranışsal Göstergeler

- Öğrenci ve ailesiyle karşılıklı güvene dayalı yakınlık kurmak amacıyla; öğrencilerin isimlerini öğrenmek ve onlara isimleriyle hitap etmek, aile bireyleriyle (en azından sorumlu veli) ile tanışmak, ders dışı yaşamlarına ilişkin sorular sormak, okul içindeki ve dışındaki akran ilişkilerine dair fikir sahibi olmak.

- Olası bir tespit sonrası konuşma sırasında kullanılan kelimelerin nasıl anlaşılabileceği hakkında düşünerek hareket etmek; yargılayıc1, emredici, suçlayıcı, korkutucu olmamak, göz teması kurmak, şefkatli olmakla birlikte öğrencinin mahrem alanına dikkat etmek, jest ve mimiklerin kontrolüne dikkat etmek.

- Olası bir tespit sonrası konuşma sırasında öğrencinin kendisini rahat hissetmesini sağlamak amacıyla öncelikle genel konularla ilgili konuşmak, güven verici bir dil ve üslup kullanmak, konuşmaya teşvik etmek, isterse çizerek veya resimle istediğini anlatabileceğini ifade etmek. 
- Öğrencileri dinlerken onlar hakkındaki ön yargıları bir kenara bırakarak iletişim kurmak. Açıklıkla ve sakince dinlemek. Öğrencide anlaşıldığı duygusunu oluşturacak bir dil kullanmak. Kendisini rahatça ifade edebilmesine müsaade etmek, istek, tercih ve beklentilerini göz önünde bulundurmak.

- Anormal davranışları gözlemlemek ve bunların sebepleri hakkında yaş, gelişim özellikleri, aile-akran ilişkileri gibi hususlar çerçevesinde değerlendirmelerde bulunmak, değerlendirmeleri daha da netleştirmek için öğrenci ile konuşmaya zaman ayırmak.

- Gözlemlenen anormal davranışlar sonucunda öğrenciyi sinirli, huysuz, agresif vb. etiket ifadelerle nitelendirmemek. Aynı zamanda olumlu da olsa motive edici etiketlendirmelerden uzak durmak.

- Öğrencide gözlemlenen anormal durumlarda okul rehberlik servisi ile iletişime geçmek ve gelecekteki iletişimi rehberlik servisi ile birlikte kurgulamak. Gerekli durumlarda okul yönetimine bilgi vermek.

- Anormal davranışlarla birlikte akademik performansa ilişkin anormal değişimleri dikkate almak ve sebepleri hakkında değerlendirmelerde bulunmak.

Tablo 6. Raporlama, Bildirim İletişimine Yönelik Davranışsal Göstergeler

- Hangi durumlarda ve ne zaman bildirimde bulunulması gerektiğini bilmek.

- Istismara dair kuvvetli bir şüpheyle karşılaşıldığında bildirimin yasal kişisel sorumluluk olduğu bilinciyle süreci başlatmak.

- Adli bildirimin yasal gerekliliklerini göz önünde bulundurmak.

- Karşılaşılan şüpheli durumla ilgili öğrenci, aile ve kurum açısından panik oluşturabilecek tutumlarda bulunmamak.

- Kurumun iç prosedürü ve yasal gerekliliklere ilişkin okul rehberlik servisi ile irtibat kurmak.

- Bildirimin bir suçlama değil, öğrencinin durumunun soruşturulup değerlendirilmesi olduğunu bilinciyle yasal sorunluluğu yerine getirmek.

- Bildirimle adli soruşturma süreçlerinin birbirinden farklı süreçler olduğunu bilmek. Öğrencinin bu durumlarda nelerle karşılaşabileceği hususunda onu korkutmadan bilgilendirmek.

- Öğrenci çok yakın bir tehlike altındaysa vakit kaybetmeden polisle iletişime geçmek.

- Bildirim sonrası yasal kişisel sorumluluğu bilmek ve kişisel gizlilik hakları hakkında bilgi sahibi olmak.

- Gizlilik ve mahremiyet ilkeleri çerçevesinde sadece ilgililerle veri paylaşımında bulunmak.

Tablo 7. Destek ve İzleme İletişimine Yönelik Davranışsal Göstergeler

- Süreci okul rehberlik servisi ve yönetimiyle işbirliği içinde yönetmek üzere destek ve izleme programı oluşturmak.

- Öğrenciye, başının belada olduğu ya da yanlış bir şey yaptığı izlenimini vermemek.

- Öğrenciye, sürece ilişkin bilgilerin rehber öğretmen ve okul yönetimi gibi ilgililer dışında hiç kimseyle paylaşılmayacağını ifade etmek.

- Öğrenciye, süreç boyunca her zaman destek olunacağı izlenimi vermek.

- İlgili birimlere intikal eden süreci takip ederek örtbas edilmesini engellemek. Sorun ve anlaşmazlıkları aşmak için müzakereye başvurmak.

- Eğitim ve iletişim süreçlerini öğrencide gelişen bilişsel, gelişimsel ve akademik problemleri göz önünde bulundurarak sürdürmek. Gerektiğinde bireysel ihtiyaçları dikkate alan eğitim ve iletişim planı hazırlamak.

- Öğrencinin istismar ve ihmal edilmiş bir çocuk olarak etiketlenmesini önleyecek ve haklarını göz önünde bulunduracak şekilde iletişim kurmak.

Tablo 8. Önleyici İletişime Yönelik Davranışsal Göstergeler

- Öğrencilerle karşılıklı güvene dayalı, saygllı iletişim kurmak, onlara değer verdiğini hissettirmek, her türlü durumda iletişime açık olunduğu mesajı vermek. Öğrencileri açık iletişim kurmaları konusunda cesaretlendirmek.

- Ebeveynlere öğrencilerle ilgili olumlu geri bildirim göndermek.

- Öğrencilere olumlu ve kolay ulaşılabilir bir rol model olmak.

- Öğrenci rehberlik servisi ve okul yönetimi ile irtibat kurarak öğrencilerin istismara ilişkin bilinç ve farkındalıklarını güçlendirecek eğitim, yaratıcı drama ve oyun imkânlarını geliştirmek.

- Kendine güveni, karar verme becerilerini, akran ilişkilerini ve öz saygiyı güçlendirecek, öğrenciyi öğrenme süreçlerine dâhil eden öğretim teknikleri kullanmak.

- Öğrenme sürecinde gerçekçi hedefler koyarak başarıya erişimi teşvik etmek ve sorun çözme kabiliyetini güçlendirmek.

- Öğrencilerin kişisel güvenlikleri ile ilgili algılarını ölçecek etkinlikler, kısa testler ve alternatif uygulamalar gerçekleştirmek.

$\mathrm{Bu}$ çerçevede katılımcılara yöneltilen sorular; ilgili fenomeni yetkin bir biçimde anlamlandırmak amacıyla en genel perspektifte i) fenomenle ilgili hangi deneyimlerin yaşandı̆̆ ve ii) hangi ortam ve 
durumların fenomenle ilgili yaşanan deneyimi etkilediği (akt. Creswell, 2018, s. 81) merkezinde kurgulanan alt sorularla organize edilmiştir.

\subsection{Verilerin Analizi}

Çalışmada verilerin analizine temel teşkil eden süreç araştırma sorularının belirlenmesinde kullanılan 4 aşamalı yaklaşımla başlamıştır. Bu yaklaşım aynı zamanda soruların belirli temalar alında hazırlanmasına olanak sağlamıştır. Bu sebeple verilerin analiz edilmesi sürecinde 2 ana başlık ve 4 alt kategoriden yararlanılmışıtır.

Tablo 9. Veri Analizinde Yararlanılan Tematik Çerçeve

\begin{tabular}{|c|l|}
\hline 1. Çocuk İstismarına Yönelik Alg1 ve Okuldaki Tecrübe & \\
\hline 2. İletişimsel Deneyim ve Yeterlilikler & $\begin{array}{l}\text { i. Tespit ve Yaklaşım İletişimi } \\
\text { ii. Raporlama-Bildirim İletişimi }\end{array}$ \\
& $\begin{array}{l}\text { iii. Destek ve İzleme İletişimi } \\
\text { iv. Önleyici İletişim }\end{array}$ \\
\hline
\end{tabular}

Bu yaklaşım çerçevesinde Creswell'in (2018, s.183) veri analiz sarmalının fenomenolojik veri analiziyle irtibatlandırılmasından hareketle aşağıdaki süreçler işletilmiştir: Verileri Düzenleme aşamasında sahadan elde edilen görüşme verileri deşifre edilerek bilgisayar dosyaları şeklinde düzenlenmiş, her bir katılımcının sorulara verdiği cevaplar alt alta yazılarak cevaplar bir araya getirilmiştir. Mülakatları bir bütün olarak anlama ve kavrama amacı güden okuma ve haturlatıc notlar alma aşamasinda ise elde edilen transkriptler detaylı bir okumaya tabi tutulmuş, temalar şeklinde parçalara ayrılmadan önce anlamlandırılmaya çalışılmıştır. Temalandırma, Simflama aşamalarına gelindiğinde, soru hazırlama sürecinde kurgulanan başlık ve kategoriler okunan metinlerin tasnifi için işlevsel bir araç olarak kullanılmıştır. Belirlenen her bir başlık ve kategori ile ilişkili olarak hazırlanan ve tüm görüşmecilere iletilen soruların cevab1 söz konusu kategoriler altında tasnif edilmiştir. Ayrıca bu başılı ve kategorilerin altında her bir soruya verilen benzer ifadelerin bir araya getirilmesiyle yeni kodlar oluşturulmuştur. Kodlardan hareketle ise yeni temalar ortaya çıkmışırı. Böylelikle de araştırma amaçlarına yönelik kapsayıcı veriler sunabilecek bir tasnife ulaşılmıştır. Ana başlık, kategoriler ve ortaya çıkan kodlama ve tamalar çerçevesinde bulgular betimlenmiş, yorumlama aşamasında ise söz konusu tasnif bir ileri safhaya taşınmıs, verilerin daha kapsamlı anlamlarına olanak sağlayan yorumlamalar çerçevesinde çocuk istismarına yaklaşımda öğretmenlerin iletişimsel deneyimlerinin özüne ilişkin çıkarımlar yapılmışıı. Araştırma verilerinin sunumunda görüşmeci ifadelerine sadık kalınmıştır.

\subsection{Etik Kurul İzni}

Bu çalışma Erciyes Üniversitesi Sosyal ve Beşeri Bilimler Etik Kurulu tarafindan, 29/09/2020 tarihli ve 142 başvuru numaralı onay formu ile etik açıdan uygun bulunmuştur.

\section{Araştırma Bulguları}

Araştırma bulgulanı, iki ana başlık ve ikinci ana başlı̆̆ genişleten dört alt başlık çerçevesinde sunulacaktır.

\section{1. Çocuk İstismarına Yönelik Algı ve Okuldaki Tecrübe}

Çocuk istismarnna yönelik okuldaki alg1 ve okuldaki tecrübeye ilişskin veriler çerçevesinde somutlaşan ilk tema istismarn kapsamı ile ilgilidir. Çocuk istismarının ne olduğu ve hangi fillerin çocuk istismarı kapsamında değerlendirilebileceğine yönelik soruya verilen cevaplar; istismarın, çocukların fiziksel ve ruhsal/psikolojik olarak zarar görmesi şeklinde genel ifadelerle açılandığını göstermektedir:

İstismar deyince çocukta olumsuz iz bırakan fiziksel, zihinsel, sosyal ve duygusal eylemlerin tamamı aklıma gelir. (Şahin)

Çocuk istismarı denilince aklıma fiziksel ve ruhsal yönden çocuğun zarar görmesi geliyor. Çocuğun bedeninde ve ruhunda yara açan her şey diyebilirim. (Şebnem)

Çocuklar yapilan fiziksel, duygusal ve cinsel yapilan her tür hal ve hareketler gelmekte. (Ali) 
Çocukların sadece fiziksel değil psikolojik olarak da gelişimini her konuda kötü, olumsuz etkileyen eylemlerin tümüne denir. (Melisa)

Ancak bu genel ve kapsamlı ifadelerin ne olduğunu biraz daha açmaları istendiğinde ve tür olarak örnekler sunmaları istendiğinde daha çok cinsel ve fiziksel istismarın ön plana çıktığ1, özellikle ihmal ve duygusal istismar türlerinin daha geri planda kaldığı görülmektedir.

Çocuğun bedeninde ve ruhunda yara açan her şey diyebilirim. Dayak yemiş, zorla işte çalıştırılmış, cinsel baskıya uğramış her çocuk istismar edilmiştir benim gözümde. (Şebnem)

Dayak atma, bağırma, konuşmamak, cinsel yapılan her tür hareketler değerlendirilebilir. (Ali)

Fiziksel şiddet uygulama, cinsel uygulamalarda bulunma, çocukla alay etme, çocuğu olumsuz şekilde sürekli eleştirme. (Şahin)

Çocuğun rızası olsun ya da olmasın bedeninin cinsel anlamda kullanılması veya çocuğun ekonomik amaçlı bir işte çalıştırılması, dilendirilmesi ve benzeri diyebilirim. (Şebnem)

İstismarın ne olduğuna ve türlerine ilişkin olarak çocuk istismar denildiğinde reşit olmayan çocuklara kendisinden büyük karşı cinsin bedenen ve ruhen kendini tatmin etmek için dokunmasıdır (Ayşe) şeklinde, sadece cinsel istismarı ön plana çıkartan net cevap veren görüşmecilerin büyük bir çoğunluğunun ilk anda cinsel istismarın zihinlerde canlandığına dair ifadeleri, diğer istismar türlerine yönelik zayıf bir kavrayışın olduğunu ortaya koymaktadır. Ayrıca öğretmenlerin okullarında karşı karşıya kaldıkları istismar vakalarına dair verdikleri örnekler bu ifadeyi destekler nitelikte yoğunlukla cinsel istismara odaklanmaktadır.

Meslek hayatımın beşinci veya altıncı yılında okulumuzdaki bir öğretmen tarafindan yine okulumuz ortaokul öğrencisine yapılan tacizle karşılaştım. Süreç hemen gerekli yerlere intikal etti. (Ayşe)

Cinsel istismara uğrayan öğrencim oldu, açıçası önce kendim olayı kabullenmeye çalıştım diyebilirim. Çünkü dinlediğim hikâyeyi hazmetmek için zamana ihtiyacım oldu. (Şebnem)

İdarecilik yaptı̆̆ım süreçte cinsel istismar olayıyla karşılaştım. Öğrenci bireysel görüşme yaptı̆̆1 süreçte rehber öğretmenine anlatmıştı olayı. Rehber öğretmen tutanak tutup emniyet güçlerine bildirdi, olay adli makamlarca takip edildi. (Gülşah)

Şu an çalıştığım okulda karşılaşmadım. Daha önce idareci olarak çalıştığım okulda karşılaştım. 8.sınıf öğrencisi evde hap içerek intihar girişiminde bulunmuş. Biz emniyet aradıktan sonra haberimiz oldu. Daha sonrasında sürekli emniyet ile irtibat halinde durumu yönetmeye çalıştım. Bu da bir cinsel istismar vakas1. (Ali)

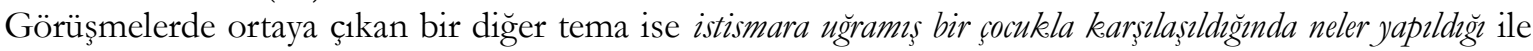
ilgilidir. Bu kapsamda mülakat sırasında öğretmenlere, sıklıkla ön plana çıkardıkları cinsel ve fiziksel istismar dışında duygusal ve ekonomik istismar ile ihmal gibi vakalarla karşılaşıp karşılaşmadıkları, karşılaştıkları takdirde nasıl bir yol izledikleri sorulmuştur. Özellikle cinsel istismar gibi vakalarda öğretmenlerin büyük bir çoğunluğu vakit kaybetmeden rehberlik servisi öğretmeni ve okul yönetimiyle irtibat kurduklarını belirtmiş ve sürecin resmi kurumlarla iletişim içerisinde yürütüldüğünü ifade etmişlerdir. Ancak diğer istismar türleri söz konusu olduğunda öğretmenler; nasıl bir yol izlemeleri gerektiği konusunda kararsız kaldıklarını ifade etmişlerdir. Bunların sebeplerine bakıldığında ise i.) yaşanan durumu tam olarak anlamlandıramama, olayın bir istismar olup olmadı̆̆1 konusunda net bir fikre sahip olmama, ii.) durumu soruşturmaya dönük çabalar sonucunda velilerden gelecek tepkilerden çekinme iii.) yaşananları görev yapılan bölgenin kültürel koşulları çerçevesinde değerlendirme gibi unsurların ön plana çıktı̆̆1 görülmektedir.

İhmal ve istismar yani bu türleri ben çok ayıramıyorum hocam. Hangi durumda ne yapacağız çok da bilmiyoruz. (Ali)

Karşılaşırsam yapılacaklar hakkında çok genel bir fikrim var ancak detaylar, izlenecek yollarla ilgili detaylandırılmış bilgilendirilmeye ihtiyacım var. Genelde ya rehber öğretmene gidelim diyoruz. Ancak böyle bir durumla karşılaşırsam diye düşündüğümde hem bir an önce maruz kalan çocuğu kurtarmam gerektiği hem de kendimi ve ailemi de korumam gerektiği düşüncesi beliriyor. Üstelik çocuğu korumak amaçlı harekete geçerken yaşanacakların ona daha da zarar vermesine neden olmak üzerdi açıkçası. Gizlilik ilkesinin ihlali istenmeyen sonuçlar doğurup zaten zarar görmüş çocuğumuzu daha da zarara uğratabilir. Bu durumu ortaya çıkarmamın bana olumsuz sonuçlar yaşatabilme ihtimali de korkutuyor. Bazen velilerin tepkisinden de bu anlamda çekiniyoruz. (Rumeysa)

Ben erkek öğretmenim mesela aile bana kız çocukla ilgili bir şey söylemiyor. Kültür çok etkili. Biz de bazen çekiniyoruz. Çok üstüne gidemiyoruz mevzunun. Ben bir durumla karşlaşınca rehber öğretmene açıyorum meseleyi direkt. Özellikle kız öğrencilerde. Onunla görüşmesini istiyorum. Onun 
ilgilenmesi daha iyi oluyor. Biz böyle durumlarda velilere de söyledim. Bizden çekinseniz dahi rehber öğretmeniyle birebir konuşabilirsiniz. (Ali)

Özellikle doğuda görev yaptığımız zamanlarda aileyle bu konuları konuşmaktan yer yer çekindiğimiz oluyordu. (Şebnem)

Mesela bir ihmal durumuyla karşılaştım. Bölgedeki koşullar gereği pek çok öğrencide bu durumun olduğunu gördüm. Böyle bir durumla karşılaştığımda aile ile maalesef iletişim kuramadım ve ben diğer arkadaşlarıma söylediğimde, aman hoca hanım boş ver bunlara takılma demeye başladılar. Yani beni tedirgin etti meslektaşlarım. Prosedürü bilmiyoruz yani elimizde bir kılavuz yok. Velilerin tepkisini alacağımız için endişeliyiz. Ben de üzerine düşemedim açıkçası. Ama o durum hala benim aklıda soru işareti olarak kald1. (Ayşe)

Ancak her ne kadar çeşitli kararsızlıklar yaşasalar da öğretmenlerin söz konusu problemlere duyarlı oldukları görülmektedir. Özellikle kadın öğretmenlerin duyarlılık vurgusu ön plana çıkmaktadır. Bu çerçevede planlı ve programlı bir yaklaşımdan ziyade kişisel çabaların ön plana çıktığı görülmektedir.

\section{2. İletişimsel Deneyim ve Yeterlilikler}

\subsubsection{Tespit ve Yaklaşım İletişimi}

$\mathrm{Bu}$ başlık kapsamında öğretmenlerin istismar süreçlerini tespit etmelerini kolaylaştıran iletişim süreçlerine yönelik görüşleriyle öğrenci ve veliye yaklaşım biçimleri, alg1 ve deneyimleri çerçevesinde ele alınacaktır. Bu noktada etkili iletişim ilk tema olarak şekillenmektedir. Öğretmenlerin, çocuk istismarryla mücadele sürecinde etkili iletişimin rolüne ilişkin görüşleri özellikle fikir düzeyinde olumlu bir görünüm arz etmektedir. Bu çerçevede etkili iletişimin temel unsurlarından güven, empatik yaklaşım, sayg1 ve etkin dinleme en çok vurgu yapılan alt temalar arasında yer almaktadır.

Öğrenci ve velilerle iletişimimde samimi, içten, seviyeli ve eğitim diliyle konuşma sağlamaya çalışırım.

Onların güvenini kazanırsak bizlere yaşadıkları olayları anlatmaya yakın görmeye başlarlar. (Ayşe)

Güven, değer ve diyaloga çok önem veririm. Öğretmen nefret edilen biri değil güven duyulan biri olmalıdır. Öğretmen beklenen, aranan biri olmalıdır. Bu durum istismar sürecini tespit etmede çok önemlidir. (Şahin)

Sevgi özellikle saygı en değer verdiğim hususlar. İletişimde objektif davranıyorum. İhtiyaç duyan her velimle özelden iletişime geçiyorum, güven duygusunu oturtmak adına konuşmalar yapıyorum. Öğrencilerimin kişisel alanlarına saygı duyuyor, bir kalem bile alırken izin istiyorum. Örnek davranışı benden görmelerini anlatarak değil yaşayarak öğrenmelerini istiyorum. (Rumeysa)

Velilerle iletişim kurarken onlara empati kurarak yaklaşırım. Onlara güven duygusunu hissettirdikten sonra istismar durumunda rahatlıkla bana gelip benden yardım alabileceklerini bilirler. (Nergis)

Mülakata katılan her bir öğretmen, etkili iletişimin önemine dair yukarıda sıralanan görüşleri paylaşmakta ve konuya ilişkin açıklamalar bu yelpazede çeşitlenmektedir. Ancak özellikle deneyim sürecinde söz konusu olumlu fikriyatın çeşitli iletişim engellerine takıldı̆̆1 ve uygulamaya tam olarak yansımadığ1 görülmektedir. Bu çerçevede fenomenolojik araştırma yaklaşımının önemle üzerinde durduğu "neyin nasıl deneyimlendiği”" hususu ayrı bir önem kazanmaktadır. O halde öğrenci ve veliyle gerçekleşen iletişim deneyiminin ortam, koşul ve içerik bakımından ne gibi değişiklikler gösterdiğini ele alarak sürecin yapısal etkiler bakımından da anlaşılması gerekmektedir. Bu noktada iletişim engelleri bir tema olarak ortaya çıkmaktadır. Öğrenciyle iletişim sürecinde önyarg1 ve etiketleme, iletişim engellerine yönelik alt temalar olarak belirmektedir.

Önyargılar çocuklarla kurulan iletişimi etkiliyor. Öğretmen ne kadar öyle değil dese de öyle. Mesela bir de şöyle oluyor. Veli ilgileniyorsa çocukla öğretmen de ilgi gösteriyor. Bazılarında da şu oluyor. Çocuk boş vermiş, hoca boş veriyor sonrasında umurlarında olmuyor olabiliyor. İdarecilik yaptığım için de biliyorum aslında öğretmenlerde genel olarak etiketleme var. Bana kaç kez geldi. Öğretmen sınıftan çocuğu göndermek için. Bu çocuk şöyle dedi. Ailesi böyle falan şikâyet ediyorlar. İlgilenmek istemiyorlar. Veya soy isimden bile. Mesela, bu soy isim bunlar işe yaramaz bunlar olmaz falan diyebiliyorlar. (Ali)

Meslek hayatımızda ön yargılı tutumları olan öğretmenlerimiz oluyor. Tabi tam tersi durumlar da nadir de olsa var. Ben bu çocuğu adam ederim. Bu çocukla ilgilenebilirim falan diye düşüneneler var. Aslında etiketleme toplumda hepimiz için geçerli aslında. Olumlu veya olumsuz etiketleme oluyor. Bu akıllı, ne bileyim bu çalışkan. Daha çok ilgi görüyor bunlar. Ama olumlu etiketler bile bazen çocuğun kendisini açmasına engel olabiliyor. (Şebnem) 
Karışmayalım gibi bir alg1 var. Çocuklar hakkındaki önyargılar onlarla iletişimi etkiliyor. Örnek vereyim. Tembel bir çocuğun sorununu öğretmen kolay kolay dinlemez. Yüzde ondur bu rakam bence. Gözde, biraz daha çalışkan öğrencilerdir. Başarılı öğrencilerdir. Öğretmen bunu üzerine biraz yoğunlaşmak ister. Onun sorunu olursa onu halletmek ister. (Şahin)

Bazı öğretmenlerin özellikle biliyorum bazı çocuklara önyargılı davranıllyor mesela. Çok tembelse mesela bırakabiliyor öğretmen. İlgilenmeyebiliyor. Veya çalışkansa beklentiler de yüksek oluyor. (Melisa)

Veliyle iletişim sürecinde ise bir önceki başlıkta vurgulandığ1 üzere velilerle ilgili çekinceler, velilerin çocuklarla ilgilenmemesi gibi sebeplerle iletişim kopukluklanı yaşanabildiği ifade edilmektedir. Eğitim süreciyle ilgili iletişim engellerine gelindiğinde ise müfredat yetiştirme kaygısı ve derslere verilen önemin derecesindeki farklılaşmaların ortaya çıkardığı sorunlar ifade edilmiştir. Müfredat kaygısı, öğrenci ve sorunlarıyla daha yoğun bir biçimde ilgilenmekten ziyade derslerin aktarımına odaklanmaya dönük bir eğitim ortamını ortaya çıkarabilmektedir. Yine özellikle Matematik, Türkçe gibi temel derslerin daha fazla önemsenmesi ve bu derslerin anlaşılmadığ1 düşünüldüğünde serbest etkinlik, beden eğitimi gibi ders saatlerinin işgal edilmesi gibi durumlar da öğrenci ile etkili iletişim kurulabilmesini zorlaştırabilecek unsurlar olarak ön plana çıkmaktadır.

Bazen müfredatı yetiştirme baskısı da oluyor tabi. İş yükü demeyeyim de kendi müfredatımı yetiştirme telaşıyla da gözümden kaçırmış olabilirim belki de. (Ayşe)

Müfredat gereğinden fazla abartılı bir şekilde yoğun, müfredatı anca yetiştirebiliyoruz. Matematik müfredatı, Türkçe müfredatı o kadar kalabalık ki. Bazen beden eğitiminden alıyoruz. Bazen müzikten alıyoruz. Serbest etkinlikler dersimiz var bazen onlardan feragat edip öteki derslere aktarmak zorunda kalıyoruz. Çocukları daha iyi tanıyacağımız zamanı diğer derslere aktarmış oluyoruz. (Şahin)

Bazen özellikle bazı hocaların öğrencileri sınava dönük hazırlama, test çözme gibi etkinlikleri idare tarafından da takdir görüyor. Bu durumlarda serbest etkinlik zamanlan mesela bunlara ayrlabiliyor. Bunun baskısını da hissedebiliyoruz zaman zaman. (Ali)

\subsubsection{Raporlama-Bildirim İletişimi}

Raporlama ve bildirim iletişimi, öğretmenin, rehberlik servisi ve okul idaresiyle işbirliği içerisinde ve yasal sorumlulukları çerçevesinde yürüttüğü etkileşim sürecine gönderme yapar. Hangi durumlarda ve ne zaman raporlama ve adli bildirimde bulunulacağını bilmek; başta çocuk ve aile olmak üzere hem kişisel hem de kurumsal düzeyde ilişki ve iletişim kanallarını doğru ve etkin bir biçimde kullanabilmek, süreçteki yeterlilikler olarak ön plana çıkar. Bu çerçevede etkili ilişki ve iletişimin ön şartı olarak ifade edilebilecek; hangi durumlarda ve ne zaman adli bildirimde bulunulacağ1 sorusu, öğretmen görüşleri çerçevesinde sahada karşılaşılan en önemli sorunu işaretlemektedir. Kavrayıs ve tespit sorunu olarak temalandırabileceğimiz probleme ilişkin görüşler şu şekilde ifade edilebilir.

Benim istismar olduğunu bilmediğim bazı konular da var. Mesela ben neyin istismara girdiğini neyin girmediğini yani bu ayrımı yapmakta zorlanıyorum. Muhtemelen okullarda hocaların böyle bir eksikliği var. Mesela bana bazı meslektaşlarım anlattı. Aile çocukların yanında cinsel içerikli filmler izliyormuş. O bize anlattı mesela böyle böyle bir olay yaşandı diye. Eminim o da bilmiyordu. Çünkü istismar olduğunu bilse bize değil de gider rehber öğretmene anlatırdı. Yani bu anlamda elimizde net bir şey yok. Yani nedir istismar, nereye kadar istismardır. Ya da neresi ihmaldir. Onu tam bilemiyoruz açıkçası. Sadece bizim aklımızda hep fiziksel istismar var. (Ayşe)

Genelde hangi durumda ne yapılacağı pek bilinmiyor. Bizim de zihnimiz bu konularda çok net değil açıkçası, bildirimin yasal sorumluluğumuz olduğunu bilmemize rağmen bazen kararsızlık yaşıyoruz. (Rumeysa)

Yönerge yok. Net bilgi yok. Elimizde hani biliyorsunuz hep yönergelerle çalışıoruz. Kanun, yönerge bizim için etken. Çünkü kendimizi güvence altında hissetmek istiyoruz. Hani bir şey olduğu zaman önce kendim güvende olayım ki çocuğa faydam olsun. Eğer kendim güvende değilsem karşı tarafa da bir şey yapmakta zorlaniyorum. Bu noktada yönergelerimiz eksik, elimizde bir veri yok. Ne yapacağımızı bilmiyoruz. Kanunen de eksiklikler var hani. Sadece bize söylenen eğer böyle bir şey tespit ettiyseniz direkt işte adli makamlara başvurun. (Gülşah)

Görüşmeci ifadelerinde karşımıza çıktı̆̆1 ve görüşme kapsamındaki hemen her sınıf öğretmeninin mutabık olduğu üzere öğretmenler; istismar türlerine, bu türlerin hangi biçimlerde karşılarına çıkabileceğine ve söz konusu istismar türlerinin anlaşılmasını kolaylaştıracak temel göstergelere yeterince 
aşina görünmemektedir. Bu durum özellikle duygusal istismar ve ihmale ilişkin görünümler için geçerlidir. Nitekim öğretmenlerin, fiziksel ve cinsel istismar türlerine karşı çok daha duyarlı olduklanı ve en kısa zamanda raporlama ve bildirim aşamalarına geçtikleri açıkça görülmektedir. Görüşmeci ifadeleri ayrıca, yer yer garip karşılanmakla birlikte daha az duyarlılık ve kavrayışa sahip olunan istismar türlerinin ipucu olabilecek bazı göstergelerin normalleştirildiğini, zaman zaman raporlama ve bildirime gerek görülmediğini ve hatta rehber öğretmen ile bile paylaşılmadığını ortaya çıkarmaktadır. Bu durumu bildirim iletişsimi engelleri teması altında ele almak mümkündür. i) Bilgi eksikliği, ii) başının belaya girebileceği düşüncesi ve endişe, iii) sorumluluktan kaçma, iv) yaşananları kültürel çevre ve etkenlerle açılama gibi durumlar söz konusu iletişim engellerinin başında gelmektedir. Bu duruma ilişkin örnekleri sırasıyla aşağıdaki görüşme verilerinde görmek mümkündür.

(Bilgi eksikliği) Ben istismar olduğunu bilmediğim bazı konular da var. Mesela ben neyin istismara girdiğini neyin girmediğini yani bu ayrımı yapmakta zorlanıyorum. (Ayșe)

(Endişe) Bazen bu konularda velileri sıkıştırdığımızda velilerin tepkisini alacağımız için endişeliyiz. Korkuyoruz açıkçası. (Nergis)

(Sorumluluktan kaçma) Bazen özellikle rehber öğretmenin olmadığı okullarda ya zaten rehberlik öğretmeni yok bu iş bana $\mathrm{m}$ kalacak. Ben mi yapacağım durumu da var. Biraz bu konu rehber öğretmene bırakıllyor. O olsaydı zaten ilgilenirdi yok. Ben sınıf öğretmeniyim bana $\mathrm{m}$ kaldı gibi yaklaşımlar olabiliyor. Bu sorunla uğraşmak zor gelebiliyor diye düşünüyorum. En azından gözlemlerim bu şekilde. (Şebnem)

(Kültürel çevre ve etkenlerle açıklama) Süreçte neyin doğru olduğunu biz çok da bilemiyoruz. Şu an hani o anlamda da bir sıkıntı var. Çocuk şiddet görüyorsa biz nereye vereceğiz. Hani bu çocuk gerçekten mutlu olacak mı? Bilmiyorum o noktada neyin doğru olduğunu biz de çok bilemiyoruz. Bir de kendi ön yaşantılarınızla bağlantılandırıyorsunuz. Ben de küçükken dayak yedim diyorsunuz falan. Kültürel etkenler de var. Bazı ailelerde bu biraz normal gibi görülüyor. (Gülşah)

$\mathrm{Bu}$ ifadeler aynı zamanda odak grup görüşmesi sırasında öğretmenlerin yaygın bir mutabakata sahip oldukları gözlemleri arasında yer almaktadır.

\subsubsection{Destek ve İzleme İletişimi}

Destek ve izleme iletişimi; rehberlik servisi ve okul yönetimiyle işbirliği içerisinde öğrenci takibinin yapılması, bireysel ihtiyaçlarını göz önünde bulunduran bir eğitim ve iletişim yaklaşımının geliştirilmesi, gizlilik ve mahremiyet kuralları çerçevesinde sürecin iyileştirilmesine gönderme yapar. Görüşme verileri bu sürecin temelde öğretmenlerin kişisel çabalar ve duyarlhlklar çerçevesinde geliştiğini, bu kapsamda vakaya özel bir eğitim ve iletişim yaklaşımının takip edilmediğini göstermektedir.

Özel bir eğitim yok açıkçası. Bu çocuğu işte şöyle yapalım böyle yapalım diye bir şey yok. Biz nasıl ki fiziksel engelli, zihinsel engelli öğrenciyi sınıfa kaynaştırmaya çalşıyorsak bunları da sınıfa kaynaştırmaya çalsşıyoruz. Ama hani buna özel bir şeyler uygulayalım tarzı bir şey yok. Hani öğretmen kendi gayretiyle çabasılyla çocuğu duygusal bağlamda besleyebilir tabi ama bununla ilgili özel bir çaba yok yani ne idareden ne de rehberlik servisinden böyle bir şey görmedik. (Şebnem)

Genel itibariyle okullarda istismar vakası yaşamış öğrencilere yönelik bireysel bir eğitim geliştirme çabası pek de yok açıkçası. Devlet okullarına baktığımız zaman özellikle iletişim ya da o çocuğa ayrı bir program çıkarmak çok zor. Çünkü sınıflar çok kalabalık. Hepsi ile bire bir ilgilenmek çok zor. Biraz da öğretmenin kendisiyle de alakalı. Bakış açısıyla da alakalı. Bence bu tarz çocuklara özel bir program yapilmıor. (Gülşah)

Bu konuda takip ettiğimiz bir program yok. Kişisel çabalar ön plana çıkıyor. (Rumeysa)

Bence bu durum öğretmende bitiyor. Yani ögretmen ben ne yapabilirim. Bu çocuğu nasıl daha iyi bir noktaya getirebilirim falan bunu düşünürse kendi bir şeyler yapabiliyor. (Melisa)

İstismar vakası yaşamış bir öğrenciye yönelik yaklaşımın daha çok kişisel çaba ve duyarllıklar düzleminde ilerlemesi bir yandan bu çerçevede geliştirilmiş bir izleme programının olmamasına bağlanabilir. Ancak öte yandan öğretmen görüşleri, böyle bir durumda özel ve hassas bir izleme ve takip sisteminin gerekliliğine yönelik duyarlllı̆̆ın da yeterince gelişmediğini ortaya koymaktadır. Bu durumda öğretmenlerin daha çok öğretmenlik eğitimi sırasında kazandıklan pedagojik birikimleri ve eğitim tecrübeleri çerçevesinde hareket ettikleri görülmektedir. 
Eğitimim ve tecrübelerim çerçevesinde öğrenciye sevecen yaklaşırım. Yaşadıklarını sorgulamam. Eğer konuşmak isterse kendisine bunun kendisinin bir suçu olmadığını anlatmaya çalışırım. Kendisini güvende hissetmesini sağlarım. Onu bir hatası kusuru olmadığını anlatmaya çalışırım. (Ayşe)

Eğitim sürecinde normal öğrencilerime ne yapıyorsam ona da aynısını yapardım. Onu diğer öğrencilerimden ayırmazdım. Tabi gözlemlerime de daha dikkat ederdim. (Ali)

Böyle bir süreçle karşılaşmadım. Karşılaşırsam eğer zaten mağdur olan öğrencimin daha da mağdur olmaması için çabalarım. Onu ötekileştirmeden, yargılamadan kendisini soyutlamasına izin vermem. Onu koşulsuz sevdiğimi hissettiririm. Rehberlik servisiyle iş birliği içinde çalışırım. Fazla abartmadan öğrencime olumlu geri dönütler veririm. (Rumeysa)

Ayrıca cinsel ve fiziksel istismar gibi daha ciddi görülen vakalarla karşı karşıya kalındığında, özellikle okul yönetiminin de etkisiyle çocuğun sınıfının ya da okulunun değiştirilmesi gibi bir kararın sıklıkla uygulandığ1 da görüşme verilerine yansıyan bir diğer husustur. Söz konusu verilere göre, bu karar vaka durumuna göre öğrenci yararına değerlendirilip uygulanabilse de en temelde bir sürece yayılan iyileştirme faaliyetinden ziyade sorunun bir an önce ortadan kaldırılmasına dönük yönetsel bir hamle olarak somutlaşmaktadır. Özellikle okul idarelerinin bu kararı almak noktasında aceleci olduğu rehber öğretmenlerle gerçekleştirilen görüşmelerde gündeme getirilmiştir. Bu çerçevede zaman zaman okul idarelerinin meseleyi imaj ve itibar odaklı, yönetsel bir çerçevede ele almaları destek ve iə̧leme sürecine yönelik iletişim engellerinden biri olarak değerlendirilebilir.

Genelde işte sınıf ya da okul değiştirme falan gibi önlemler alınıyor ki. Çocuk hani başka bir ortama girsin. Kimsenin haberdar olmadığı bir yerde olsun falan oluyor. (Ali)

Bence bu tarz çocuklara özel bir program yapılmıyor. Sadece ne yapılıyor. Okulu değiştiriliyor eğer ciddi bir problem yaşadıysa; çünkü duyulmuştur o çevrede. Okulu değiştirmesi konusunda veliye bir şeyler söyleniyor. Özellikle idare tarafindan. Bu şekilde belki bir önlem olabilir. Zaten her okulda da rehber öğretmen olmayabilir. (Gülşah)

Hocam bu bazen çocuğun da faydasına olan bir durum olabiliyor. Çocuğun da menfaatleri göz önünde bulundurulduğunda okulun değişmesi gibi kararlara rastliyoruz ve rehber öğretmenler olarak biz de bunlara onay veriyoruz. (Selahattin)

Çocuğun okul değişimi tamamen işbirliği içinde alınması gereken bir karar. Çocuk, aile, öğretmen, rehber öğretmen ve idareciler bu konuda çocuk merkezli bir karar almalı. Tabi maalesef her zaman böyle olduğunu söylemek çok güç. İdareler aman okulumuzun itibarı önemli falan gibi hususları daha ön plana çıkartıyorlar gibi. (Tülay)

Tüm bunların yanında öğretmenlerin, öğrenci mahremiyeti konusunda yüksek duyarlılık sahibi oldukları ve konuya empatiyle yaklaştıklan görülmektedir. Bu durum destek ve izleme sürecinin söz konusu önemli boyutuna ilişkin yüksek bir duyarlılığın geliştiğini göstermektedir.

\subsection{4. Önleyici İletişim}

Okul ortamlarında önleyici iletişim, olası istismar vakalarını henüz ortaya çıkmadan engellemeye olanak sağlayacak iletişim ve eğitim yaklaşımının sergilenmesi olarak ifade edilebilir. Bu çerçevede öğretmenin; öğrenciler, ebeveynler, rehber öğretmenler ve okul yönetimiyle işbirliği içerisinde olması önem arz etmektedir. Öğrenci ve ebeveynle açık ve güvene dayalı bir iletişim kurmak, erişilebilir olmak, olumlu rol model teşkil etmek; rehber öğretmen ve okul yönetimiyle işbirliği içerisinde önleyici eğitim, oyun ve drama vb. gibi faaliyetler organize etmek ve eğitim yoluyla öğrencilerin kişisel güven, özsayg1 ve karar verme becerilerine katkı sağlayacak eğitim yaklaşımlarını sergilemek önemli yeterlilikler arasındadır. Bu kapsamda Öncelikle öğretmenlere "sizce bir öğretmen nasıl bir eğitim ve iletişim yaklaşımı kurgularsa istismar vakalarını önleyici tedbirler almış olur” şeklinde bir soru yöneltilmiştir. Önleyici iletişimde ideal yaklaşım teması altında sunulabilecek bu cevaplar öğretmenlerin zihnindeki ideal yaklaşımı ifade etmesi bakımından önemlidir. Farkındalık oluşturma, hayır demeyi öğretme, güvenlik alg1sı eğitimi, güvene dayalı ilişki, kişisel haklanı tanıma, bedeni tanıma, özel bölgelere yönelik farkındalık gibi hususlar söz konusu tema altında ifade edilebilecek alt temalar arasında yer almaktadır.

Bence çocuklara kendi bedeni, kimliği, kişiliği, gelişim süreçleri öğrencinin yaşına uygun olarak anlatılmalıdır. Bedeninin kendisine ait olduğu, isteği dışında dokunuşların iyi veya kötü olduğu, bu dokunuşları nasıl ayırt edeceği öğretilmelidir. Hangi durumların istismar olduğu farkındalık çalışması yaptırılmalıdır. (Ayşe) 
Öğretmen öğrencilerine hayır diyebilmeyi öğretmeli, çocuğa iyi ve kötü davranışların neler olduğunu öğretmeli, öğretmen öğrenciyle iletişim sürecini sürekli açık tutmalı ve en önemlisi çocuğa özgürce konuşmaya izin verecek bir ilişki kurmalı ve ortam sağlamalıdır. (Şahin)

Bence öğretmen öğrencisine güven vermelidir. Öğrenci o güveni gördüğünde kimseye anlatamadiğ1 yaşadığı olay ya da vakalanı öğretmenine anlatacağını düşünüyorum. Öğrenci ile tek başına sohbet etmelidir. Bu sohbet öğrenciyi yargılayıcı değil rahatlatıcı olmalıdır. (Ali)

Öğrencinin yaş grubuna uygun olarak öğrenciye bedenini tanıması ve zarar verildiğinde ne yapması gerektiği anlatılmalıdır. Çocuk haklanndan haberdar edilmeli, hakların ihmal edildiği durumlarda nerelere başvurabileceği öğretilmelidir. (Gülşah)

Çocuğa açık bir dil ile koruması gereken bölgelerini anlatmalıdır. Anne baba dışında kim olursa olsun o bölgelere kimsenin dokunmaması gerektiğini anlatacaktır. (Nergis)

Öğretmenlerin ideal düzeyde kodladıkları önleyici iletişim ve eğitim yaklaşımlarını ne ölçüde gerçekleştirebildikleri, bu konuda kendilerini yeterli hissedip hissetmedikleri konusuna gelindiğinde ise önemli iletişim engellerinin ortaya çıktı̆ııı ifade etmek mümkündür. Bu çerçevede i.) yetersizlik hissi ve bilgi eksikliği, ii.) yalnızca müfredata bağlı kalma ve iii.) sorumluluğun rehber öğretmen ve idareye ait olduğunu düşünme önleyici iletişim engelleri teması altında ifade edilebilecek hususlar arasında yer almaktadır.

Evet, belki ideal olan şeylerden bahsettim ama yer yer ben dahi hangi şartlar çocuk istismarına girer çok ayrıntısını bilmiyorum. Fiziksel dokunuş hariç. (Ayşe)

Bahsetmiş olduğum tüm bu davranışları ne kadar yapıyorum diye sorarsanız kısmen diyebilirim. Kullandığım yöntem ve tekniklerin çok da yeterli olduğunu düşünmüyorum açıkçası. (Nergis)

Yani bizim Hayat Bilgisi dersimiz var ve bu derste genel olarak bu tür konulardan bahsediyoruz. Ama özellikle bu konuda ayrıca ciddi bir çabamızın olduğunu söyleyemem. (Melisa)

Bizim sınıf öğretmenliği müfredatımızın içinde. Hayat bilgisi, Sosyal Bilgiler dersleri günlük hayatımızla ilgili bazı kazanımları vermeye çalışıyor. Direkt adı istismar olmasa da kişisel özel alan, hayır deme vesaire gibi uygulamalar var tabii. Müfredatın içine entegre edilmiş şeyler var. Ancak bunu aşıp bir şey yapmiyor pek de öğretmenler. (Şebnem)

$\mathrm{Bu}$ konularda müfredata bakıllyor genelde. Bizim Türkçe müfredatında ya da Hayat Bilgisi müfredatında zaten aile arasında ilişkiler, arkadaşlar arası ilişkiler, dış çevre ile ilişkiler falan var oradan takip ediyoruz. (Şahin)

$\mathrm{Bu}$ tarz işler genelde rehber öğretmenin işi gibi alg1lanır. O yüzden idare de öğretmen de bu konuda biraz pasiftir. İdarenin de bu konuda herhangi bir planı yok. Öğretmenlerin de bir talebi yok. Öğretmen müfredatla cebelleşmeye çalışıyor. İdare bunun kendi görevi olmadığına inanıyor. Bu tip programlarla pek uğraşılmıyor maalesef. (Şahin)

Gözlemlerim çerçevesinde söylüyorum öğretmenler bu işi biraz da rehber öğretmenin ya da idarenin işi olarak görüyorlar. (Ali)

İstismar vakalarına yönelik önleyici iletişimin öğretmenler tarafından rehber öğretmenlerin görev ve sorumlulukları dâhilinde görülmesi, rehber öğretmenlerle gerçekleştirilen görüşmelere de yansıyan bir husustur. Bu çerçevede rehber öğretmenler (Fatma, Selahattin, Tülay) idare ile diğer öğretmenler arasında kaldıklarını hem idarenin hem de diğer öğretmenlerin bu çerçevede kendilerinden büyük beklentiler içinde olduklarını ve yer yer böyle durumlarda tek sorumluluk sahibi olarak kendilerinin görüldüğünü ifade etmişlerdir. Son olarak diğer yaklaşım türlerinde olduğu gibi önleyici iletişim ve eğitim yaklaşımında da kişisel çabaların ve yüksek sorumluluk bilincinin olumlu anlamda farklılaşan uygulamalara sebebiyet verdiği hemen her öğretmenin ifade ettiği bir husus olarak ön plana çıkmaktadır.

\section{Tartı̧̧ma, Sonuç ve Öneriler}

Çocuk istismarı, dünya çapında ürettiği yaygın etki ve sonuçlarla en temelde bir insanlık sorunu olarak karşımıza çıkmakta, bu sorunla mücadele ise çok yönlü çabaları gerekli kılmaktadır. Diğer önemli çabaların yanında özellikle akademik girişim düzeyindeki disiplinlerarası çalışmalar; meselenin çok yönlü bir biçimde ele alınması, soruna ilişkin farklı bileşenlerin ve karmaşık yönlerin açıklığa kavuşturulması bakımından önleyici çabalar olarak önem arz etmektedir. Bu sebeple eğitim ve iletişim bilimlerinin kesişimindeki bu araştırma girişimi, sınıf öğretmenlerinin çocuk istismarına yönelik iletişimsel deneyim ve yeterliliklerine odaklanarak alana ilişkin literatüre katkı sağlamayı amaçlamıştır. Çocuk istismarıyla mücadelede stratejik bir potansiyel içeren öğretmenlerin hem konuya ilişkin bilgi, bilinç ve farkındalıkları hem de soruna dair süreç yönetimi becerileri açısından iletişim merkezli araştırmalar ciddi bir önem arz etmektedir. 
$\mathrm{Bu}$ çerçevede çocuk istismarına yönelik alg1 ve okuldaki tecrübe başlı̆̆ ile birlikte, çalışmada kurgulanan dört aşamada sınıf öğretmenlerinin iletişimsel yaklaşım ve deneyimlerine ilişkin sonuçlar şu şekilde ifade edilebilir:

i.) Araştırma bulguları, çocuk istismarının, katılımcı sınıf öğretmenlerinin zihinlerinde daha çok cinsel ve fiziksel istismar şeklinde bir karş1lık bulduğunu ortaya koymaktadır. Yine bulgular, bahsi geçen istismar türlerine ilişkin duyarlılığın da fazla olduğunu göstermektedir. Duygusal istismar ve ihmal gibi türlere ilişkin görünümler ise ya bilgi eksikliği sebebiyle yeterince anlamlandırılamamakta ya da zayıf duyarlılık, yaşananları, görev yapılan bölgenin kültürel koşulları çerçevesinde değerlendirerek önemsememe ve velilerden gelecek tepkilerden çekinme gibi sebeplerle göz ardı edilebilmektedir.

Fiziksel ve cinsel istismar dişındaki istismar türlerine ilişkin bilgi, farkındalık ve duyarlılık eksikliği en temelde istismarın tespitine, raporlanmasına ve önlenmesine dönük “iletişim engelleri” olarak değerlendirilebilir. Bu noktada ögrretmenlerin istismar türlerine ilişkin bilgi, bilinç ve farkındalıklarının arttırılması önemli bir gereklilik olarak ortaya çıkmaktadır.

ii.) İstismar vakalarının okul içerisinde tespit edilebilmesi, etkili bir öğretmen-öğrenci iletişimiyle birlikte veliler, rehber öğretmenler ve okul idaresiyle de etkili bir iletişimi gerekli kılmaktadır. Araştırma, çocuk istismarıla mücadele sürecinde etkili iletişimin rolüne ilişkin öğretmen görüşlerinin özellikle fikir düzeyinde olumlu bir görünüm arz ettiğini ortaya koymaktadır. Ancak konuyla ilgili deneyimlere gelindiğinde söz konusu olumlu fikriyatın çeşitli iletişim engellerine takıldığı ve uygulamaya tam olarak yansımadığ1 görülmektedir.

$\mathrm{Bu}$ çerçevede ön yarg1, ön kabul ve etiketleme, öğrencilerle ilgili iletişim engelleri olarak somutlaşmaktadır. Ön yarg1 ve ön kabullerle gelişen etiketleme özellikle öğretmenler tarafindan gerçekleştirildiğinde, öğrencilerin, kendilerine yapıştırılan etiketlere uygun davranış pratiklerini pekiştirmesine sebebiyet verebilmektedir. Etiketlemenin her zaman olumsuz olması da gerekmez. Örneğin öğretmeni tarafindan sürekli akıllı, başarılı ve uslu olarak etiketlenen bir çocuk, öğretmeninin gözündeki imajını bozmamak için yaşadığı sorunları baskılama ve öğretmeniyle paylaşmama eğilimi içerisine girebilmektedir.

Velilerden çekinme, velilerden çocuklarıyla daha fazla ilgilenmelerini bekleme gibi sebepler de velilerle ilgili engeller olarak somutlaşmaktadır. Katılımcı görüşleri, öğretmenlerin zaman zaman velilerden tepki görecekleri endişesiyle onlarla irtibat kurmak noktasında tedirginlik yaşayabildiğini göstermektedir. Müfredat yetiştirme kaygısı ve derslere verilen önemin derecesindeki farklılaşma gibi öğrencileri daha yakından tanımaya ve etkili iletişim kurmaya olanak sağlayan serbest zaman etkinliklerine ayrılan zamanı önemli ölçüde azaltan sebepler ise eğitim süreciyle ilgili iletişim engelleri olarak ortaya çıkmaktadır.

Ancak tüm bunların yanında mülakat süreci, kişisel faktörlerin etkili iletişimde çok önemli bir yeri olduğunu ortaya koymaktadır. Görüşmeciler, öğretmenlerin kişilik tipleriyle birlikte cinsiyet ve yaş gibi hususların da etkili iletişim sürecinde olumlu veya olumsuz anlamda belirleyici olabileceğini ifade etmişlerdir. İstismar özelinde kadın öğretmenlerin daha anaç ve korumacı bir tavra sahip oldukları, ayrıca öğrencilerle kurulan iletişimde erkek öğretmenlere göre daha rahat oldukları gözleme dayalı görüşler olarak hemen her öğretmen tarafından paylaşılmaktadır. Ayrıca özellikle son yıllarda artan hizmet içi eğitimlerin de etkisiyle daha genç yaşlardaki öğretmenlerin her ne kadar vaka ile karşılaşma hususunda tecrübesiz olsalar da konuya ilişkin daha fazla duyarlılık sahibi oldukları da ifadelere yansıyan bir diğer husustur.

iii.) Bulgular, sınıf öğretmenlerinin cinsel ve fiziksel istismar türlerine ilişkin kavrayış ve duyarlılıkları sebebiyle bu tür sorunlarla karşılaştıklarında hızlı bir biçimde gereken adımları attıklarını göstermektedir. Ancak duygusal istismar ve ihmal gibi türlere gelindiğinde özellikle kavrayış ve duyarlılık eksikliği sebebiyle, zaman zaman istismar türlerinin ipucu olabilecek bazı göstergelerin normalleştirilebildiğini, raporlama ve bildirime gerek görülmediğini ve hatta rehber öğretmen ile dahi paylaşılmadığını göstermektedir. Bildirim iletişimi engelleri teması altında ele alınan bu durumda i) bilgi eksikliği, ii) başının belaya girebileceği düşüncesi ve endişe, iii) sorumluluktan kaçma, iv) yaşananları kültürel çevre ile açıklama gibi engellerle karşılaşılmaktadır.

Sınıf öğretmenlerinin yalnızca istismar türlerine değil yasal sorumluluklarına ve hangi durumda bildirimde bulunmaları gerektiğine ilişkin bilgi, bilinç ve farkındalıklarının arttırılması önemli bir gereklilik olarak ortaya çıkmaktadır. 
iv.) Araştırma bulguları, katılımcı sınıf öğretmenlerinin, istismara maruz öğrencilere yüksek bir empati ve mahremiyet duyarlllığıla yaklaştığını göstermektedir. Ancak buna rağmen sınıf öğretmenlerinin, sorumluluklan kapsamında vakaya özel bir eğitim ve iletişim yaklaşımı geliştirmesinden ziyade sürecin öğretmenlerin kişisel çabaları ve duyarlılıkları çerçevesinde geliştiği görülmektedir. Bu durum sınıf ögrretmenlerinin aynı zamanda destek ve izleme süreçlerinin önemi ve gerekliliği konusundaki farkındalıklarının da yeterince gelişmediğini göstermektedir.

Söz konusu eksiklik sadece sınıf öğretmenlerinde değil okul idarelerinde de gözlemlenen bir gerçeklik olarak rehber öğretmen görüşlerine de yansımıştır. Buna göre özellikle cinsel ve fiziksel istismar gibi daha ciddi görülen vakalarla karşı karşıya kalındığında okul idarelerinin öğrencinin okulunun değiştirilmesine yönelik kararlar alabildikleri görülmektedir. Sorunun bir an önce ortadan kaldırllmasına odaklanan bu tür hamleler ise sürece yayılan bir destek ve iyileştirme yaklaşımından ziyade imaj ve itibar odaklı yönetsel çabalar olarak ön plana çıkmaktadır.

v.) Bulgular, tüm katılımcıların istismar vakalarının henüz ortaya çıkmadan önlenmesine yüksek bir önemle yaklaştıklarını göstermektedir. Ancak uygulama düzeyinde birtakım sorunların ortaya çıktı̆ı görülmektedir. Konuya ilişkin yetersizlik hissi ve bilgi eksikliği bunun temel sebepleri arasındadır. Aynı zamanda önleyici eğitim ve iletişim yaklaşımlarının geliştirilmesi ve uygulanması konusundaki sorumluluğun rehber öğretmen ve idareye ait olduğu düşüncesi de önemli bir sorun olarak belirmektedir. Uygulama düzeyindeki eksikliklere gelindiğinde ise önleyici iletişim ve eğitim yaklaşımının sadece müfredatın kendilerine sunduğu ilgili temalar ve kişisel çabalar etrafında şekillendiği görülmektedir.

Tüm bu ifadelerden hareketle sınıf öğretmenlerinin genel olarak istismar vakalarına duyarlı bir yaklaşım sergiledikleri; ancak istismar dendiğinde daha çok fiziksel ve cinsel istismara yönelik bir algının ortaya çıkması sebebiyle bu duyarlılığın duygusal istismar ve ihmal için yeterince geçerli olmadığı ifade edilebilir. Bunun en temel sebebi ise söz konusu istismar türlerine ilişkin bilgi ve farkındalık eksikliği olarak somutlaşmaktadır. Söz konusu eksiklik; istismarın tespiti, raporlanması ve adli bildirim, destek ve izleme süreçleri ile önleyici iletişim yaklaşımlarının geliştirilmesinin önündeki en önemli engellerden birini teşkil etmektedir. Bunun dışında bahsi geçen her bir aşamada öğretmen, veli, eğitim süreçleri ve okul yönetimi kaynaklı önemli iletişim engellerinin ortaya çıtı̆ğı görülmektedir. Söz konusu bilgi eksikliği ve iletişim engellerine yönelik çözüm önerilerinin geliştirilmesi, istismara ilişkin okul toplumu üyelerinin tamamını ilgilendiren karmaşık sorunlara yanıtlar üretilebilmesi için önemli bir gereklilik arz etmektedir.

\section{Extended Abstract}

Child abuse "includes all types of physical and emotional ill-treatment, sexual abuse, neglect, negligence and other forms of abuse which results in actual or potential harm to health, development, the dignity of the child aged under 18 in the context of a relationship of responsibility, trust or power"(WHO, 2016). Lately, statistical data published on this subject in particular to Turkey show the common occurrence of the problem whose basic types are expressed above as well as showing that it is an issue that needs to be addressed diligently to consider the best interests of children. Additionally, the data increase the importance of scientific data and of reflecting this information in policies and trainings, and make cooperation in this subject important. In this context, this study, which was prepared within the scope of the "Strengthening Teacher Competencies for the Detection and Prevention of Child Abuse" Project by the short name ProChild funded under the Erasmus + Program Strategic Partnership for School Education actions carried out by the Turkish National Agency, addresses communicative experiences and competencies of primary school teachers within the framework of the stages of the communicative approach to child abuse.

Scientific information that can be reflected in relevant policies and training is quite important for strengthening the professional formations of anti-abuse occupational groups. Teachers come first among the groups whose knowledge, skills, and awareness should be increased in this process. The role, importance, knowledge, and awareness of teachers at different levels have been addressed in many studies. While some of these studies have general quality (Erol, 2007; Scholes et al., 2012), a significant part of them are related to the role of primary school teachers (Bülbül et al., 2019; Vitalaki, 2013) and counselor teachers (Cowan et al., 2019; Kemp, 1981; Yolcu, 2009). 
This study presents an innovative appearance due to the fact that it aims to focus on the communicative experiences and competencies of teachers within the framework of a four-stage approach related to experiences of teachers and how they experience these in the communicative approach to child abuse. In this regard, this study was designed with a qualitative character and phenomenological study design and was conducted with eight primary school teachers and three counselor teacher through focus group interviews and in-depth interviews. In accordance with this general purpose and design, answers were sought for the following questions:

1. How do primary school teachers perceive child abuse and what experiences have they had concerning abuse?

2. What are the perceptions and experiences of primary school teachers related to the communicative approach that facilitates detecting abuse?

3. What are the perceptions and experiences of primary school teachers about communicative competencies in the reporting of abuse and the legal reporting process?

4. What are the perceptions and experiences of primary school teachers related to the communicative approach to the processes of support and monitoring after cases of abuse?

5. What are the perceptions and experiences of primary school teachers about the preventive communication and training approaches related to the abuse?

In this regard, the results regarding the communicative approach and experiences of primary school teachers in the four stages set up in this study with the title of perceptions and experience in school regarding child abuse can be stated as follows:

i.) The findings of the study reveal that child abuse corresponds to sexual and physical abuse in the minds of the participating primary school teachers. Additionally, the findings show that the sensitivity towards the aforementioned forms of abuse is more. Views related to forms like emotional abuse and neglect either cannot be understood enough due to lack of knowledge or are disregarded due to the reasons such as weak sensitivity, disregarding what happened by considering it within the framework of the cultural conditions of the region, and being afraid of reactions from parents.

Lack of knowledge, awareness, and sensitivity towards the forms of abuse except physical and sexual abuse can be regarded as "communication barriers" for the detection, reporting, and prevention of abuse. At this point, increasing the knowledge and awareness of teachers about the forms of abuse emerges as an important requirement.

ii.) Detecting cases of abuse within the school requires effective teacher-student communication as well as effective communication with parents, guidance teachers, and school administration. It is revealed in this study that the opinions of teachers about the role of effective communication in the fight against child abuse have a positive outlook, especially at the intellectual level. However, the abovementioned positive opinions come across various communication barriers and are not reflected in the practice fully considering the relevant experiences of teachers.

However, the interview process reveals that personal factors have an important part in the effective communication. The interviewers stated that factors such as sex and age in addition to character types of teachers might be positive or negative determinants in the effective communication process. As observational opinions, almost all teachers expressed that female teachers have a more maternal and protective attitude, and they are also more comfortable in communication with students than male teachers in the context of abuse. Additionally, it was stated that although younger teachers are inexperienced in terms of encountering a case of abuse, they are more sensitive about the subject with the influence of lately increasing in-service trainings.

iii.) The findings show that primary school teachers rapidly take the necessary steps when they encounter such a problem due to their understanding and sensitivity about sexual and physical forms of abuse. However, it was shown that from time to time some indicators that may be a clue to the forms of abuse can be normalized, reporting and notifying are not required and even not shared with the counselor due to lack of understanding and sensitivity considering emotional abuse and neglect. In this situation which is addressed under the theme of reporting communication barriers, the following obstacles are 
faced: i) lack of knowledge, ii) the thought that one might get into trouble and worry, iii) avoidance of responsibility, and iv) explaining what happened with the cultural environment.

Thus, the knowledge and awareness of primary school teachers not only about the forms of abuse, but also about their legal responsibilities and when they should report must be increased.

iv.) The findings of the study show that primary school teachers approached abused students with a high sense of empathy and privacy. However, it is observed that the process is continued with the personal efforts and sensitivities of teachers rather than developing a training and communication approach specific to the case within the responsibilities of primary school teachers. This shows that the awareness of primary school teachers about the importance and necessity of support and monitoring processes is not raised sufficiently.

The aforementioned deficiency is reflected in the opinions of counselor teachers as a reality observed not only among primary school teachers but also among school administrations. Accordingly, it is also observed that school administrations decide that the student should change schools, especially when faced with more serious cases such as sexual and physical abuse. Such moves that focus on eliminating the problem as soon as possible come to the forefront as administrative efforts oriented at image and reputation rather than a support and improvement approach.

v.) The findings show that all primary school teachers attach great importance to preventing cases of abuse before they occur. However, it is seen that several problems occur in practice. The sense of incompetency and lack of knowledge about the subject is among the main reasons for that. Also, the thought of the primary school teachers that it is the responsibility of guidance counselor and school administration to develop and implement preventive training and communicative approaches is another important problem.

According to all these statements, primary school teachers mostly display a sensitive approach towards cases of abuse, but this sensitivity is not valid enough for emotional abuse and neglect due to the fact that they have a perception of abuse based on physical and sexual abuse. The main reason for this is the lack of knowledge and awareness regarding the types of abuse. This deficiency is one of the most important obstacles to the development of preventive communication approaches with the detection, reporting, and legal notice, support, and monitoring processes. Additionally, it is observed important communication barriers due to teachers, parents, educational processes and school administration arise at each aforementioned stage. It is highly necessary to develop solution proposals for the abovementioned lack of knowledge and communication barriers to provide answers to complex problems that concern all members of the school community regarding abuse.

\section{Kaynakça}

Abrahams, N., Casey, K., \& Daro, D. (1992). Teachers' knowledge, attitudes, and beliefs about child abuse and its prevention. Child Abuse \& Neglect, 16(2), 229-238. https://doi.org/10.1016/01452134(92)90030-U

APSAC. (1995). Psychosocial evaluation of suspected psychological maltreatment in children and adolescents: Practice guidelines. American Professional Society on the Abuse of Children. https://www.apsac.org/single-post/2017/12/05/APSAC-Practice-Guidelines-Now-Free

Buluş, M., Atan, A., \& Sarıkaya, H. E. (2017). Effective communication skills: A new conceptual framework and ccale development study. International Online Journal of Educational Sciences, 9(2). https://doi.org/10.15345/iojes.2017.02.020

Butchart, A., Phinney Harvey, A., Mian, M., \& Fürniss, T. (2016). Çocuklara kötü muamelenin önlenmesi: Bu konuda harekete geçilmesine ve kanıt toplanmasına yönelik bir kılavuz / Preventing child maltreatment: A guide to taking action and generating evidence / World Health Organization and International Society for Prevention of Child Abuse and Neglect. Uluslararası Çocuk Merkezi Derneği. https://apps.who.int/iris/bitstream/handle/10665/43499/9241594365_tur.pdf?sequence=21\&isAllowed $=\mathrm{y}$

Bülbül, K., Çakici, A. B., \& Türkkan, T. (2019). Sınıf öğretmenlerinin çocuk istismarı ve ihmaline yönelik bilgi ve risk tanıma düzeylerinin incelenmesi. Türkiye Eg̈itim Dergisi, 4(2), 127-144. 
Chaiyachati, B. H., \& Christian, C. W. (2019). Child physical abuse: An overview. İçinde Encyclopedia on Early Childhood Development [online] (ss. 1-6). http://www.childencyclopedia.com/sites/default/files/textes-experts/en/779/child-physical-abuse-an-overview.pdf

Christian, C. W., \& States, L. J. (2017). Medical mimics of child abuse. American Journal of Roentgenology, 208(5), 982-990. https://doi.org/10.2214/AJR.16.17450

Cowan, R., Cole, R., \& Craigen, L. (2019). School-Based Child Sexual Abuse Prevention: Implications for Professional School Counselors. 9, 200-210. https://doi.org/10.15241/rc.9.3.200

Creswell, J. W. (2018). Nitel araştırma yöntemleri: Beş yaklaşıma göre nitel araştırma ve araştırma deseni (M. Bütün \& S. B. Demir, Çev.). Siyasal Kitabevi.

Erol, D. (2007). Okulöncesi eğitim kurumlarında görev yapan öğretmenlerin, çocuklardaki fiziksel istismar belirtilerine ilişkin farkındalıkları [Anadolu Üniversitesi Eğitim Bilimleri Enstitüsü]. https://tez.yok.gov.tr/UlusalTezMerkezi/TezGoster?key=-Z0vbSUgrhM9fXoGkRe6QxAj8z9xu-

YCo1Xz7TbFWo30rtKj0do_ejo_Rbcqrqed

Kara, B., Biçer, Ü., \& Gökalp, A. S. (2004). Çocuk istismarı. Çocuk Sağhlğ ve Hastahklar Dergisi, 47(2), 140-151.

Kemp, K. (1981). Child abuse and neglect: The role of the School counselor. American Secondary Education, 11(2), 12-15. JSTOR.

Koç, F., Halıcıoğlu, O., \& Akşit, S. (2014). Hangi bulgular fiziksel istismarı düşündürür? The Journal of Pediatric Research, 1(1), 1-5. https://doi.org/10.4274/jpr.57966

Korkut Owen, F., \& Bugay, A. (2014). İletişim Becerileri Ölçeği’nin geliştirilmesi: Geçerlik ve güvenirlik çalş̧ması. Mersin Üniversitesi Eğitim Fakültesi Dergisi, 10(2), 51-64.

Milli Eğitim Bakanllğı Rehberlik ve Psikolojik Danışma Hizmetleri Yönetmeliği, 31213 (2020). https://www.resmigazete.gov.tr/eskiler/2020/08/20200814-2.htm

Merriam, S. B. (2013). Nitel araştırma: Desen ve uygulama için bir rehber (S. Turan, Çev.).

Öztürk, S. (2007). Çocuklarda duygusal istismar [Yüksek Lisans Tezi, Firat Üniversitesi Sosyal Bilimler Enstitüsü Eğitim Bilimleri Anabilim Dalı]. https://tez.yok.gov.tr/UlusalTezMerkezi/TezGoster?key=ePX_SaJ0b35Gq45swKG31KeX4gIOOtKcm QNs1TUgyp4CTZKsjGzGTqH8MaoLRXwJ

Polat, O. (2018). Türkiye'de çocuk istismarı raporu -2 . http://cohum.giresun.edu.tr/Files/ckFiles/cohum-giresun-edu-tr/RAPOR-\%C3\%87OCUK-

$\%$ C4\%B0ST\%C4\%B0SMARI-tam_v2_cleancopy.pdf

Polat, O. (Ed.). (2019). Tüm boyutlarılla çocuk istismarı-I Tanımlar (3. baskı). Seçkin.

Scholes, L., Jones, C., Stieler-Hunt, C., Rolfe, B., \& Pozzebon, K. (2012). The teachers' role in child sexual abuse prevention programs: Implications for teacher education. Australian Journal of Teacher Education, 37. https://doi.org/10.14221/ajte.2012v37n11.5

Sezer, N. (2017). Etkili iletişim kavramı ve süreci. İçinde Etkili İletişim Becerileri (ss. 31-54). İstanbul Üniversitesi Açık ve Uzaktan Eğitim Fakültesi.

Şahin, F., Özdinç, B., Paslı, F., Kaynak, H., \& Hatipoğlu, N. (2008). Çocuk ihmali ve istismarını önleme: Öğretmenler ve aileler için eğitim kılavuzu. İnsan Hakları Derneği. https://ihd.org.tr/images/pdf/cocuk_ihmalini_ve_istismarini_onleme_ogretmenler_ve_aileler_icin_egiti m_klavuzu.pdf

Taşkin, P., Erdemli, Ö., \& Demir, T. G. (2019). Çocuğun ihmal ve istismardan korunmasında okulun rolüne ilişkin öğretmen görüşleri. Mehmet Akif Ersoy Üniversitesi Eğitim Fakültesi Dergisi, 52, 65-95. https://doi.org/10.21764/maeuefd.563292

Tower, C. C. (1992). The role of educators in the prevention and treatment of child abuse and neglect. U.S. Department of Health and Human Services Administration for Children and Families Administration on Children, Youth and Families National Center on Child Abuse and Neglect. https://rhyclearinghouse.acf.hhs.gov/sites/default/files/docs/1424-

The_Role_of_Educators_in_the_Prevention_and_Treatment_of_Child_Abuse_and_Neglect.pdf

UNICEF. (2015). Cinsel istismar mağduru çocuklara bakım kılavuzu: İnsani yardım ortamlarında sağlık ve psikososyal hizmet sunucuları için kılavuz. International Rescue Committee. 
https://www.unicef.org/turkey/sites/unicef.org.turkey/files/2019-

02/Cinsel $\% 20$ istismar $\% 20$ magduru $\% 20$ cocuklar.pdf

Veltkamp, L. J., \& Miller, T. W. (1994). Clinical handbook of child abuse and neglect. (ss. xiii, 167). International Universities Press, Inc.

Vitalaki, E. (2013). The child abuse matter and the major role played by the teacher: Issues raised by a pilot focus group sample of primary teachers. Journal of Education and Learning, 2. https://doi.org/10.5539/jel.v2n1p84

World Health Organization. (2016). Child maltreatment. World Health Organization. https://www.who.int/en/news-room/fact-sheets/detail/child-maltreatment

Yildiz, D., Kiliç, M. Y., \& Yavuz, M. (2018). "Öğretmenlerin iletişim becerilerini değerlendirme ölçeği” Geliştirme Çalışması. Ana Dili Eğitimi Dergisi, 6(1), 48-67. https://doi.org/10.16916/aded.345518

Yolcu, H. (2009). İstismara uğramış çocuğa eğitim ortamında yaklaşım: Rehber öğretmenin rolü.

Yüksel-Şahin, F. (2016). İletişim becerilerine genel bir bakış. İçinde Kişilerarası İlişkiler ve Etkili İletişim (ss. 32-62). Pegem Akademi. 